Riofrío-Calderón, G., Ramírez-Montoya, M. S., \& Rodríguez-Conde, M. J. (2016). Mediation practices for learning in MOOC courses to promote open innovation. In Proceedings of the Fourth International Conference on Technological Ecosystems for Enhancing

Multiculturality, TEEM 16.

\title{
Mediation practices for learning in MOOC courses to promote open innovation.
}

\author{
Gioconda Riofrío-Calderón \\ Universidad Técnica Particular de Loja \\ San Cayetano Alto \\ Loja-Ecuador. \\ 5933701444 ext. 2224 \\ gcriofrio@utpl.edu.ec
}

\author{
María-Soledad Ramírez- \\ Montoya \\ Tecnológico de Monterrey \\ Avda. Garza Sada 2501 sur; col. \\ Tecnológico \\ solramirez@itesm.mx
}

\author{
María-José Rodríguez-Conde \\ GRIAL Research Group \\ Research Institute for Educational \\ Sciences, \\ University of Salamanca \\ Paseo de Canalejas 169, 37008 \\ Salamanca, Spain \\ (+34) 923294500 ext. 3433 \\ mjrconde@usal.es
}

\begin{abstract}
SUMMARY
With the increase of the training offered in online environments over the last decade, one of the key elements in these training events is mediation as an enabler best results approval and learning achievements. In this context the role of mediation is key, especially when there is no teacher or tutor figure that is in contact with the participants. The aim of this research, that is derived from a doctoral program, is to analyze the practices of mediation in massive courses open (MOOC for its acronym in English) in the areas of energy sustainability and propose a mediation model that considers the open innovation as a key element. In this way answers the research question regarding the relationship between the practices of teaching and learning technological mediation with MOOC courses. The research is the result of cooperation between government institutions in Mexico such as CONACYT and SENER with the Technological Institute of Monterrey, the latter by offering 10 massive courses on the subject of energy sustainability, whose course name in spanish is: "Generación de energias y limpias y energias convencionales" [Generation of clean energy and conventional energy], and its participantes constitute the research population, who, through various instruments of qualitative and quantitative, will be consulted regarding mediation and its relationship with learning. The results of this study allow thus to answer the research question, in addition to the generation of proposals in the field of mediation that promote open innovation. It is expected that the results represent a contribution in the sense of determining the relationship mediation - outcomes of learning in MOOC courses.
\end{abstract}

\section{Key words}

Open innovation, mediation, MOOC, education.

\section{BACKGROUND AND MOTIVATION}

In 2016 the project called Laboratorio Binacional for the intelligent management of energy sustainability and technological training between the National Council of Science and Technology of Mexico, and the Ministry of Energy and the Technological Institute of Monterrey, is created, this project comprising several Sub- projects focused in the field of energy sustainability. In this context, the Sub project was born: open, interdisciplinary and collaborative innovation through MOOC, which has within its training objectives, the implementation of 10 courses MOOC on issues of energy sustainability to favor the formation of professionals energy sector, as well as students and the general public interested in issues of energy and its efficient use.

Training through MOOC constitutes a fundamental fact, considering that this resource is characterized [10] "to have a social focus, boost learning communities and break the traditional model". The success that these courses are having excels in its wide acceptance and [9] the MOOC 2015 amounted to more than five million students. The big challenge for the development of these courses is good design, which if its not there it will represent serious problems for achieving the objectives [7]. These aspects should be presented to the training offer energy sustainability, This training plan is expected to reach a population of 15,000 participants.

It is based on this training offer that the present research work graduate arises, which aims to analyze the practices of mediation in the course generation of clean conventional energy, to establish the relationship between the pedagogical and technological mediation results 
learning. The research question is what is the relationship between pedagogical practices and technological mediation with massive open learning courses aimed at fostering open innovation practices?

\section{STATE OF THE ART}

Innovation represents development, evolution, but as researchers say innovation alone is not enough, today we speak of an open, external system, which crosses borders, hence open innovation [6] is based on a form of knowledge and different logic on the sources and use of ideas, which come from inside or outside the company, is a different and opposite to the closed innovation conception. [19] innovation refers to an action that involves the development, the realization of something new, within a system, process, organization, whose aim is to improve the products. [12] on open innovation rightly they point out that the lack of openness to external environments reflects poor vision, represents progress disconnect from third and a disadvantage in the competition.

Education for its part has also innovated their processes, their offer and are especially universities with the emergence of distance education and technology developments that have undergone significant changes and transformations. So since the beginning of this decade as a result of open innovation that has revolutionized educational settings are the MOOC [11] that allow to materialize the dream of many educators which is to achieve in people quality education through a system education for thousands to a system for millions.

Massive open courses MOOC, [17] are a recent development in the field of distance education or distance learning. The MOOC [5] represent one of the most innovative and inspiring to project the work to society alternatives. According to data on the web, there are several platforms that manage MOOCs and these in turn are offered by universities around the world. According to the study [16] it is evident that in Latin America but growing; It is still low supply of MOOC in relation to Europe which quadruples its offer. In this type of courses the presence of mediators elements that stimulate the learning process is essential.

On the web there are reports everywhere on this global phenomenon, however, as there are positive views, there are also serious doubts about its results and [3] the MOOC are online courses and put in doubt by making them massive has an added value both pedagogical and psychologically. In the same line [22] indicate that additional potential offered in education globally, in this type of training are opportunities and threats. [4] these courses have attracted attention not only in higher education but also other educational levels. These courses should adopt different teaching strategies such as role of mediation to promote a more personalized learning that lead to certification and accreditation.

\section{Mediation in open environments}

Although there are various types of mediation in the literature, it is the pedagogical and technological mediation those that were formed for the analysis of this investigation and mediation particularly focused on massive open environments. [18] referring to mediation in virtual environments, indicates that mediate virtuality means expanding the possibilities of the student in the teaching-learning process, but I will not leave, it also expresses that through mediation it seeks to change behavior, a fact that it is feasible thanks to social interactions. In teaching [1] sense includes mediation instruments character cognitive, physical, instrumental that make feasible the development of cognitive activity and achieving goals. Moreover they emphasize that mediation allows the student passing a non-expert level to one that called expert knowledge

The pedagogical [2] mediation is "treatment of contents and forms of expression of the different themes that make possible the educational act" and technological mediation express that it involves the existence of complex powers whose foundation is technological development to transform reality and that electronic devices are mediators in human action. [21] regarding the pedagogical mediation considers that it is not any activity, but it is a practice done with a purpose, it is not a simple interaction because it transforms, modifies and builds people. [14] in the study on online mediation in distance education courses they indicate that the teacher's role is to mediate Development Zone East in line with the thinking of Vygotsky, that is, encourage their development. MOOC around [20] in such a confluence of technological and pedagogical mediations is given, although they are explored in all its dimensions. It is essential therefore consider mediation as an essential element when building massive courses open.

\section{HYPOTHESES}

In this research work the following hypotheses are proposed:

If mediation pedagogical practices and technological practices, in massive open courses of energy sustainability as a mechanism to promote open innovation and contributes to the learning process, are developed.

Null hypothesis: 
The development of mediation educational practices and technological in massive open courses of energy sustainability as a mechanism to promote open innovation does not contribute to the learning process.

\section{RESEARCH OBJECTIVES}

With this research we seek to analyze the practices of pedagogical and technological mediation in the massive open MOOC of energy sustainability ongoing to determine the need and importance of mediation as well as the relationship between the pedagogical and technological mediation with learning, in order to propose a model for open mass mediation courses that consider open innovation as a key element.

Specific objectives

1. Determine the mediators elements and indicators set in the pedagogical and technological field in massive courses as open innovation models.

2. Analyze the relationship between the pedagogical and technological mediation with an open learning course massive energy sustainability.

3. Propose a model of pedagogical and technological mediation processes open and innovative training to generate better results in the MOOC.

\section{METHODOLOGY}

The methodology to be implemented in the research corresponds to mixed one, i.e, that which is the result of qualitative and quantitative approaches [13] is developed from the two main types of research. Regarding its use, [8] mixed methods are a mix of quantitative and qualitative and also that these methods are being mostly used in the social and human sciences.

The research incorporates the quantitative study through analysis of the data obtained in the course of energy sustainability. Clean energy generation and conventional energies and also the qualitative study that will be conducted through different techniques that will compare the results.

\section{Population and sample}

As part of the SENER project - CONACYT of Mexico with the Technological Institute of Monterrey through the binational Laboratory will launch ten massive open courses of energy sustainability, so in this study population is made up of the course participants Generation clean energy and conventional energy. Also an involved teaching team is responsible for the design and development of the course. For selection, the mixed sampling for qualitative approach intended stratified sampling (purposive sampling technique) and the quantitative approach the (probability sampling technique) [23] simple random sampling is used.

\section{Study variables and instruments:}

The research variables are: Open innovation and pedagogical and technological mediation, which will be analyzed through tools and techniques as:

1. Survey.- To MOOC participants to determine the characteristics, elements and results of pedagogical practices and technological mediation in the MOOC, generation of clean energy and conventional energy.

2. Questionnaire.- useful in determining the attitudes and perceptions of MOOC participants towards achieving their learning.

3. Interview.- oriented to the teaching team responsible for planning and development of MOOC of clean generation and conventional energies, where we expected to meet his conception of MOOC respect of mediators elements, in addition to its structure , expectations and expected results

4. Direct observation: It allows finding and assessing practices of mediation in the course open to analyze massive and accordingly determine the relationship with the results of the participants.

\section{Information Sources}

1. Participants: from the MOOC enrolled in the course with whom the information of how it has influenced the practice of pedagogical and technological mediation and relationship learning outcomes will be generated 
2. Teaching Team: responsible for the design and implementation of energy sustainability MOOC courses to learn how the pedagogical and technological mediation addressed and through which items or activities evidence.

3. Relevant documents: information constituted by SENER Project - CONACYT to detect what awaits the project with the supply of energy sustainability MOOC courses to assess and influence of open innovation as a key element in this process of formation.

4. Artifacts platform where courses are offered energy sustainability.

5. Digital Material, such as Scopus documents, ERIC, ISI Web, books, magazines, articles which disclose the state of the variables involved and the related work.

\section{Collect and analysis of information}

A pilot instruments to participants of MOOCs (survey and questionnaire survey monkey or other tool) in the first phase test is conducted.

- Improving the tools based on the results of the pilot test.

- Application of the instruments in the first phase of the teaching team for the sample.

- Analysis of data from the first phase of sources and instruments, with SPSS and NVivo.

- Drafting of the results of the first phase.

- Pilot instruments in the second phase (interview and observation) Test.

- Improving the tools based on the results of the pilot test.

- Instruments to apply selected participants in the second phase for the sample.

- Analysis of the data of the second phase with a triangulation of sources and instruments, with SPSS and NVivo.

- Drafting of the results of the second phase.

With regard to data analysis [15] one of the interesting results of the joint research is that it can be addressed in a single study issues from different perspectives. In the same line of mixed methods [24] with the use of mixed methods it has a better understanding of the problems, which does not happen if one approach is followed. To carry out the investigation, there will be used the ethics guide American Statistical Association

\section{RESULTS}

The development of the research is to identify practices mediation in MOOC and determine how these practices contribute to the learning process. Specifically the relationship between the pedagogical and technological mediation in massive open courses will be analyzed. With the analysis of the course on energy sustainability it is also expected to know how to influence mediation fundamental to society today theme, and is expected to generate results that will raise and lay the foundation of the mediating elements to be considered in a MOOC

\section{STATE OF THE THESIS}

At the moment has been performed literature review, critical to building the theoretical framework, at the same element that the course generation of clean energy and conventional energy, with which it will work on the collection and analysis of data is in the development phase by the Monterrey Institute of Technology team.

\section{CURRENT CONTRIBUTION AND EXPECTATED CONTRIBUTIONS}

With the development of this research it is expected to generate a model of mediation in massive courses open as a contribution to the academic community where mediators elements become evident both in the pedagogical part as a technology to be considered in the design of a training proposal that promotes open innovation

\section{ACKNOWLEDGEMENT}

This research has been conducted within the PhD Program in Education in the Knowledge Society of the University of Salamanca. The study is registered under the Project 266,632 "Binational Laboratory for Intelligent Energy Management Sustainability and Technology Training", with funding from the Energy Sustainability Fund CONACYT -SENER (Call: S0019-2014 01 ). Support for the Fund and the Tecnologico de Monterrey as the project is appreciated. 


\section{REFERENCES}

[1] Alzate, M., Arbelaez, M., Gómez, M., and Romero, F. 2005. Intervención, mediación pedagógica y los usos del texto escolar. Revista Iberoamericana de Educación, 37 (3), 1-15. Retrieved from https://dialnet.unirioja.es/servlet/articulo?codigo=3197147

[2] Avogadro, M. and Quiroga, S. 2016. La mediación tecnológica y las TIC fenómenos y objetos técnicos. Razón y palabra. Primera Revista Electrónica en Iberoamérica Especializada en Comunicación, (92), 1-18. Retrieved from https://dialnet.unirioja.es/servlet/articulo?codigo=5444643

[3] Bartolomé, A. and Steffens, K. 2015. ¿Son los MOOC una alternative de aprendizaje? Comunicar 22(44), 91-99. Retrieved from http://www.redalyc.org/articulo.oa?id=15832806010

[4] Brahimi, T. and Sarirete, A. 2015. Learning outside the classroom through MOOCs. Computers in Human Behavior, 51, 604-609. DOI= http://dx.doi.org/10.1016/j.chb.2015.03.013

[5] Caballo, M., Caride, J. A., Gradaílle, R. and Pose, H. M. 2014. MOOCS like university spread. [Los massive open on line courses (MOOCS) como extensión universitaria] Profesorado, 18(1), 43-61. Retrieved from http://www.ugr.es/local/recfpro/rev181ART3.pdf

[6] Chesbrought, H. 2003. Open innovation. The New Imperative for creating and profiting from technology. Harvard Business Scholl. Boston, Massachusetts.

[7] Conole, G. 2013. Los MOOCs como tecnologías disruptivas: estrategias para mejorar la experiencia de aprendizaje y la calidad de los MOOCs. Campus Virtuales. Revista Científica Iberoamericana de Tecnología Educativa, 2(2), 16-28.

[8] Creswell, J. 2003. Reserarch design. Qualitative, quantitative, and mixed methods approaches. Sage publications: Thousand Oaks, California.

[9] Daniel, J., Vázquez Cano, E., and Gisbert, M. 2015. The Future of MOOCs: Adaptive Learning or Business Model? RUSC. Universities and Knowledge Society Journal, 12(1), 64-73. DOI= 10.7238/rusc.v12i1.2475

[10] Fidalgo-Blanco, Á., Sein-Echaluce Lacleta, M. L., Borrás Gené, O., and García-Peñalvo, F. J. 2014. Educación en abierto: Integración de un MOOC con una asignatura académica. Education in the Knowledge Society (formerly Revista Teoría de la Educación: Educación y Cultura en la Sociedad de la Información), 15(3), 233-255.

[11] Flores, J., Cavazos, J., Alcalá, F. and Chairez, A. 2013. Los MOOCs: Una revolución para la transición a la Sociedad del Aprendizaje. SCOPEO Observatorio de la Formación en Red. Informe Nro. 2. ISSN: 1989-8274 Retrieved from http://scopeo.usal.es/wp-content/uploads/2013/06/scopeoi002.pdf

[12] García-Peñalvo, F. J., García de Figuerola, C., and Merlo, J. A. 2010. Open knowledge: challenges and facts. Online Information Review, 34(4), 520-539. DOI=10.1108/14684521011072963

[13] Johnson, R. and Onwuegbuzie, A. 2004. Mixed methods research: A research paradigm Whose time has come. Educational research, 33(7), 14-26.

[14] Oliveira, F., Albuquerque, H., Cagnoto, C. and Lombardi, R. 2015. Mediações on-line em cursos de educação a distancia. Revista Brasileira de Educação, 20(61), 359-382. DOI= 10.1590/S1413-24782015206105

[15] Onwuegbuzie, A. J., and Johnson, R. B. 2006. The validity issue in mixed research. Research in the Schools, 13(1), 48-63. Retrieved from https://scholar.google.com.ec/ 
[16] Pérez, M., Maldonado, J. and Morales, N. 2016. Status Report on the adoption of MOOCs in Higher in Latin América and Europe. MOOC-Maker Building Management Capacity for MOOCs in Higher Education 1 (s/n), 1-37. Retrieved from http://www.mooc-maker.org/wp-content/files/D1.1-InformeMOOCLatam-vFINALDEFINITIVO_English.pdf

[17] Poy, R. and Gonzales-Aguilar, A. 2014. Factores de éxito de los MOOC: algunas consideraciones críticas. Revista Ibérica de Sistemade y Tecnologías de información, E1(03), 105-118. DOI=10.4304/risti.e1.105-118

[18] Ramírez, D. and Chávez, L. 2012. El concepto de mediación en la comunidad del conocimiento. Sinéctica Revista Electrónica de Educación. 39. Retrieved from http://www.sinectica.iteso.mx/index.php?cur=39\&art=39_06

[19] Ramírez, M. S. 2012. Modelos y estrategias de enseñanza para ambientes innovadores. Editorial Digital, Tecnológico de Monterrey.

[20] Raposo, R. 2015. Orientaciones pedagógicas para los MOOC. Retrieved from http://gtea.uma.es/congresos/wpcontent/uploads/2013/12/Texto_Congreso-MRaposo-def.pdf

[21] Sanceverino, A. 2016. Pedagogical mediation in youth and adult educación. Revista Brasileira de Educação 21(65), 455-475. $\mathrm{DOI}=10.1590 / \mathrm{S} 1413-24782016216524$

[22] Schuwer, R. and otros. 2015. Opportunities and Threats of the MOOC Movement for Higher Education: The European Perspective. The International Review of Research in Open and Distributed Learning, 16(6), 20-38. DOI= 10.19173/irrodl.v16i6.2153

[23] Tashakkori, A. and Teddie, C. 2003. Handbook of Mixed Methods in Social y Behavioral Research. Thousand Oaks CA, EE.UU: Sage 273-294.

[24] Valenzuela, J. R., and Flores, M. 2012. Fundamentos de investigación educativa. Volúmenes 2 y 3 (eBook). México: Editorial Digital Tecnológico de Monterrey. 